This is a pre-print of an article published in Environmental Earth Sciences The final authenticated version is available online at:

https://doi.org/10.1007/s12665-018-7698-6 
Caetano Luiz BEBER ${ }^{\text {a }}$, Rafael da Rosa COUTO ${ }^{\text {a }}$, Paulo Emílio LOVATO ${ }^{\text {a }}$, JeanPhilippe GUILLEMIN ${ }^{\mathrm{b}}$, Bernard NICOLARDOT ${ }^{\mathrm{b}}$, Jucinei José COMIN ${ }^{\mathrm{a}}$, Ricardo Bergamo SCHENATO ${ }^{c}$

\title{
COMPARATIVE AGROENVIRONMENTAL RISKS OF PESTICIDES IN DIFFERENT CROPPING SYSTEMS: APPLICATION OF THE I-PHY INDICATOR
}

\footnotetext{
${ }^{a}$ Departamento de Engenharia Rural - Centro de Ciências Agrárias da Universidade Federal de Santa Catarina. Rod. Admar Gonzaga, 1346 - Itacorubi, Florianópolis - SC, 88034-000, Brasil ${ }^{b}$ Département Agronomie, Agroéquipements, Élevage et Environnement - AgroSup Dijon Institut National Supérieur des Sciences Agronomiques, de l'Alimentation et de l'Environnement. 26 Boulevard Dr Petitjean, 21000 Dijon, França ${ }^{c}$ Departamento de Ciência do Solo - Centro de Ciências Rurais da Universidade Federal de Santa Maria. Av. Roraima, 1000 - Camobi, Santa Maria - RS, 97105-900, Brasil
}

Corresponding Author: Caetano Luiz BEBER ${ }^{1}$ - cbeber@gwdg.de

Telephone: +49 $55139-4869$

Rafael da Rosa COUTO² - rrccouto@hotmail.com

Paulo Emílio LOVATO - paulo.lovato@ufsc.br

Jean-Philippe GUILLEMIN - jp.guillemin@agrosupdijon.fr

Bernard NICOLARDOT - b.nicolardot@agrosupdijon.fr

Jucinei José COMIN - j.comin@ufsc.br

Ricardo Bergamo SCHENATO - ribschenato@gmail.com

\begin{abstract}
:
Agricultural activities are responsible for causing impacts to the environment depending on the practices adopted during the production process. In order to access the risks of those practices, measurement tools are necessary. This paper concerns the empirical application of the environment assessment indicator I-Phy, an indicator measuring the risks of pesticide usage in agriculture. Five crops in two different climate regions were assessed, a tropical and a temperate, and three different cropping systems: no-tillage, minimal tillage and conventional tillage. No-tillage generally presented risks of environmental pollution slightly lower in both regions. High environmental vulnerability of the fields and the numerous applications of active substances with high risks exhibit high risks of general contamination. The I-Phy indicator can be useful as a support tool to farmers and research and extension institutions pursuing management practices with lower impact on the environment.
\end{abstract}

Key Words: pesticide indicator, environmental assessment, no tillage, I-Phy

\footnotetext{
${ }^{1}$ Present address: Georg-August-Universität Göttingen - Department of Agricultural Economics and Rural Development (DARE) - Platz der Göttinger Sieben 5, 37073 - Göttingen

2 Present address: Programa de Pós-graduação em Ciência do Solo - Univerisdade Federal de Santa Maria. Av. Roraima nº 1000, cidade universitária, Santa Maria, RS, 97105-900, Brasil.
} 


\section{INTRODUCTION}

Environmental assessment methods are needed to reconcile high performance of cropping systems with the demand for more sustainable farming practices (ThiolletScholtus and Bockstaller 2015). Impacts from agricultural activities are usually associated with pesticide use, both in tropical and temperate regions.

Pesticide use in a cropping system may result in surface- and groundwater contamination, air pollution, and accumulation in soils. Cropping system, soil type, relief, rainfall, and slope shape and length, all may affect prediction of transported particle size distribution (Flanagan and Nearing 2000). Tillage and other agricultural practices can determine runoff volume and subsurface drainage (Boyd et al. 2003); (Xie, Chen, and Shen 2015), and consequently affect the amount of nutrients and pesticides leached from agricultural fields, thus affecting their environmental risks and impacts.

Brazil has become the largest consumer of pesticides worldwide, with a great spectrum of active ingredients and chemical groups, gaps on the legislation regulating pesticide, lack of training and pressure of industry in many ways (Pedlowski et al., 2012). The impact of pesticides are well documented in Brazil, including cases of suicide (Krawczyk et al., 2014), changes in immune and endocrine markers (Raphael et al., 2011), fetal exposure in utero (Ferreira et al., 2013) and cutaneous melanoma (Segatto et al., 2015).

The large impact of pesticide use on agriculture has led to different studies using a range of phytosanitary indicators (Bockstaller et al. 2009). Phytosanitary treatments were compared in many different environmental situations and crop-specific conditions (Roussel, Cavelier, and van der Werf 2000), (Tixier et al. 2007), (Combret et al. 2007), (Hernández-Hernández et al. 2007), (Thiollet-Scholtus and Bockstaller 2015). In such studies, indicators consider differently the environment characteristics, and assign more or less importance to each of them in the impact evaluation.

The impact of an increasing number of pesticides is not simple to access and to express in a comprehensive base. The I-Phy index consider the active ingredient, the characteristics of the plot and the application to identify which practices are generating 
the main environmental risks of phytosanitary treatments in different scenarios of crop production.

The I-Phy index has been used in different soil conditions, climates, crops, system arrangements and scales, moreover, the constant improvements is an determining factor to the robustness and applicability of models and indexes. Lindahl and Bockstaller (2012), as example, incorporating a mechanistic approach, that allows to consider preferential flow and calculate the risk to groundwater.

To address those issues, we assessed the environmental impacts of pesticide use in systems with soils managed in conventional system (CS), minimum tillage (MT) and no tillage (NT) in two different regions. The regions assessed were Is-sur-Tille in France, and Ituporanga in Brazil. Those are two important agricultural regions in their respective countries, and they have a long history of pesticide use in different crop systems and the associated environmental impacts. We adopt here the indicator I-Phy (van der Werf and Zimmer 1998) which has been designed for arable crops in France. Adaptations were made to use it in Ituporanga/SC. I-Phy is an indicator belonging to the environmental assessment method INDIGOß (aka IPest).

Our first objective is to apply the indicator I-Phy with modifications in a subtropical environment. Secondly we wish to compare three soil management systems, both having a long history of pesticide use, in two distinct regions.

In the first part of this paper, we give an overview on both regions and their environmental characteristics, and in the second part the methods are presented with a description of the I-Phy indicator. In sequence we present the Results and Discussion of our analysis followed by the conclusions.

\section{MATERIALS AND METHODS}

\subsection{I-Phy}

The I- Phy Indicator is based on fuzzy logic, which deals with variables that can have heterogeneous nature and limited accuracy associated in a rule-based decision system. This system can be summarized by a decision tree, in which the choice of a variable implies the choice of the next variable, until the last step leads to the final indicator (Bockstaller and Girardin 2008), as shown in Figure 1. This approach allows aggregation of quantitative and qualitative variables, such as characteristics of the active 
substance, the environment and application conditions. It also considers qualitative loss mechanisms crossed with toxicity. In the construction of the indicator I- Phy (van der Werf and Zimmer 1998), four types of risks are considered: (I) the risk of leaching toward groundwater (RESO), (II) the risk of surface water contamination (RESU), (III) the airborne contamination risk (RAIR) and (IV) the risk of environmental presence (DOSE). The risks are constructed with variables for which a favorable class (low risk) and an unfavorable class (high risk) are defined.

Each of these four types of risk is expressed on a scale from 0 (highest risk) and 10 (minimum risk). To calculate those risks the indicator uses physico-chemical characteristics and toxicity of the molecule, environmental information (slope, soil organic matter, distance from surface water bodies, crop species, etc.), and application mode (date, dose, soil-incorporated or surface application, application on the entire field or on bands, etc.) as summarized in table 2 . indicator.

\begin{tabular}{|c|c|c|c|c|c|}
\hline Variables & Units or modalities & Dose & Groundwater & $\begin{array}{l}\text { Surface } \\
\text { water }\end{array}$ & Air \\
\hline & \multicolumn{5}{|c|}{ Variables linked to the active substance } \\
\hline Half-Life (HL 50) & days & & & $\mathrm{x}$ & $\mathrm{x}$ \\
\hline GUS $^{(1)}$ & - & & $\mathrm{x}$ & & \\
\hline Henry Constant $\mathrm{K}_{\mathrm{H}}^{(2)}$ & - & & & & $\mathrm{x}$ \\
\hline $\mathrm{ADI}^{(3)}$ & mg.kg ${ }^{-1}$ & & $\mathrm{x}$ & $\mathrm{x}$ & $\mathrm{x}$ \\
\hline \multirow[t]{2}{*}{ Aquatox $^{(4)}$} & $\operatorname{mg} .1^{-1}$ & & & $\mathrm{x}$ & \\
\hline & \multicolumn{5}{|c|}{ Variables linked to the environment (plot) } \\
\hline Leaching potential & between 0 et 1 & & $\mathrm{x}$ & & \\
\hline Drift percentage $\mathrm{e}^{(5)}$ & $\%$ & & & $\mathrm{x}$ & \\
\hline \multirow[t]{2}{*}{ Runoff potential } & between 0 et 1 & & & $\mathrm{x}$ & \\
\hline & \multicolumn{5}{|c|}{ Variables linked to application conditions } \\
\hline Application Dose & $\mathrm{g} \mathrm{ha}^{-1}$ & $\mathrm{x}$ & & & \\
\hline Application Position & $\begin{array}{c}\text { Into or over the soil or over the soil } \\
\text { cover ( } \% \text { soil cover) }\end{array}$ & & $\mathrm{x}$ & $\mathrm{x}$ & $\mathrm{x}$ \\
\hline \multicolumn{6}{|c|}{$\begin{array}{l}\text { Adapted from (Werf \& Zimmer, 1998). (1) Ground Water Ubiquity Score: index expressing the leaching potential } \\
\text { f the active substance. GUS }=\log 10 \text { (TD50) }(4-\log 10)(\text { Koc), where Koc is the coefficient of the division organic } \\
\text { arbon-water from the molecule. (2) Dimensionless variable determining the risk of volatilization the active } \\
\text { ubstance. (3) Acceptable Daily Intake (human toxicity). (4) Toxicity to wildlife (fish, etc.) and aquatic flora (algae). } \\
t \text { uses the highest toxicity for the three groups of aquatic organisms. (5) Expressed in \% of active substance spread } \\
\text { epending on the distance of the river. It was considered that a risk of drift }>1 \% \text { is totally acceptable. }\end{array}$} \\
\hline
\end{tabular}

Environment-related risks are measured by estimations related to risk potential of some factors, e.g., soil organic matter content was used to estimate leaching potential.

87 Drift relates to the amount of product that can be found directly in a watercourse (ditch, 88 water well or other water source). Potential for surface runoff is based on slope 
inclination, since a moderate slope may allow flow, unlike erosion itself, strongly linked to steeper slopes. Soil cover is based on early crop establishment and treatment dates.

3.3 Method of calculation I-Phy (adapted from van der Werf and Zimmer (1998) and Bockstaller and Girardin (2008)).

The calculation can be performed at different levels depending on the type of information aimed, and done in the following order:

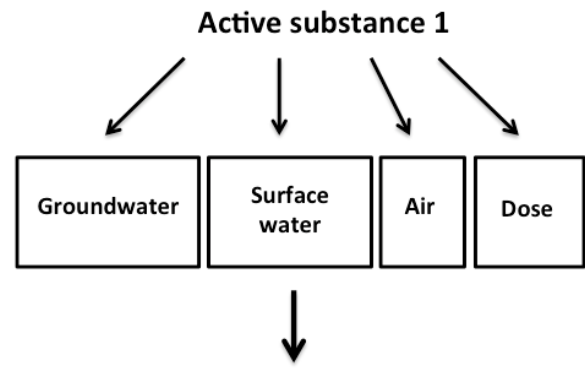

Calculate of overall risk $=$ Indicator for active substance (I-Phyma)
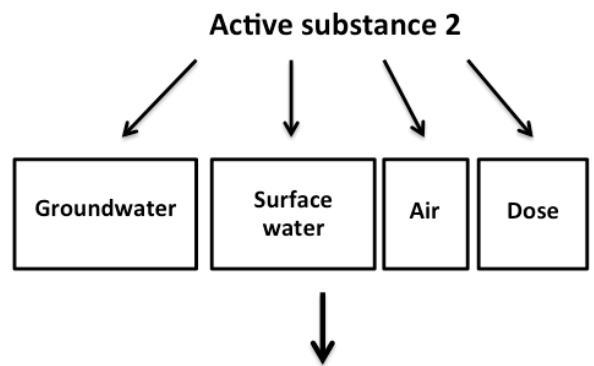

Calculate of overall risk = Indicator for active substance (I-Phyma)
95

Figure 1: Steps of I-Phy indicator determination (adapted from van der Werf and Zimmer, 1998).

Step 1: Calculation of a risk per module for each application of a given active substance. It is based on four modules: the environmental compartments of groundwater, surface water, air, and dose-associated risk.

Step 2: Calculation of an indicator (Iphysa) for each application of an active substance.

The four risks are combined with the same method using fuzzy logic (it is neither an addition nor a calculation of the mean) for a global risk rated from 0 (highest risk) to 10 (zero risk), depending on the active substance dose.

Step 3: Calculation of a global indicator on a program of treatments applied over a crop. 
The risk linked to a treatment program is due to either a treatment with high risk

109 (estimated by the minimum values of the indicators for each treatment (Iphysa), or to a

110 program including a large number of low-risk treatments, according to equation 1.

$111 \quad$ Equation 1:

$$
\begin{gathered}
I-P h y=\min \left(\text { Iphysa }_{i}\right) \times \sum K i \times\left(10-\text { Iphysa }_{i}\right) \div 10+k_{i} \times(10 \\
\left.-\min \left(\text { Iphysa }_{i}\right) \div 10\right)
\end{gathered}
$$

112 Where:

113 Iphysa $a_{\mathrm{i}}$ : indicator for the application of active substance $\mathrm{i}$;

$114 \mathrm{k}_{\mathrm{i}}$ weighting coefficient empirically obtained by regression $(\mathrm{k}=0,1$ to Iphysa $=$ $11510, \mathrm{k}=0.2$ to Iphysa $=7$ and $\mathrm{k}=1$ to Iphysa $=2$ ). It is obtained from equations 2 and 3.

$116 \quad$ Equation 2:

$117 \quad k=1,7175 \times e^{(-0,2913 \times I \text { Iphysa })}$

$118 \quad$ Equation 3:

$\left.119 \sum \sum k \times\left(10-\min \operatorname{Iphys}_{i}\right) \div 10\right)$, that represents the sum of the weighted risks 120 less the minimum value Iphysa.

121 Figure 2 shows the decision rules for calculation of overall risk.

122 For each figure, the white boxes represent the cases in which the variable is 123 favorable and dark boxes represent cases in which the variable is unfavorable. 


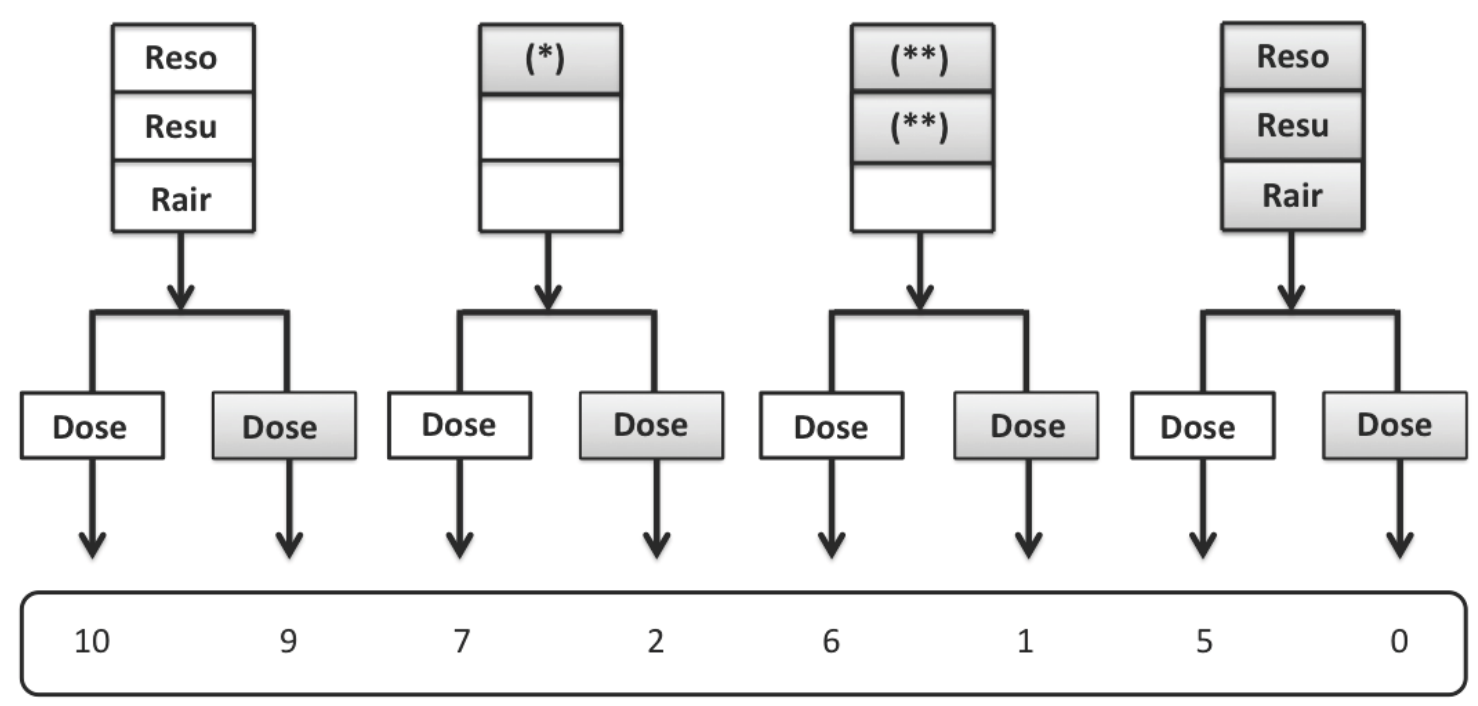

$(*)$ - One of the three modules Reso, Resu, Rair takes an unfavorable value $(=0)$

$\left({ }^{* *}\right)$ - Two of the three modules Reso Resu, Rair takes an unfavorable value $(=0)$

Figure 2: Rules of decision tree for the calculation of the overall risk per active substance of the I-Phy (adapted from Bockstaller et al. 2008).

A decision tree is constructed with the following hypotheses:

a) No weighing is made among the modules of risk to groundwater, surface water, and air.

b) A low dose significantly minimizes risk. If, in the case of a totally unfavorable value in one of the compartments, dose is very low and favorable, the indicator score is set at the limit of 7 , expressing the minimum acceptable in INDIGO ${ }^{\circledR}$ method.

The general structure of the I-Phy highlights the architecture of interactions between input data, which describe farming practices, climate, field characteristics and the active substance used, as well as the calculation processes and the ultimate indicator.

\subsection{Field characteristics and Data collection}

The data was collected in 26 farms from the two regions totaling 43 fields, 12 in No Tillage, 17 in Minimal Tillage and 14 in Conventional. The description and the insertion in the local context are as follows.

The main crops in the Is-sur-Tille (Burgundy/France) region are wheat, barley and rapeseed, with cropping systems heavily dependent on agrochemicals. The area is crossed by the Ignon River, which at certain times of the year has contamination 
144 problems, caused mainly by nitrates, phosphates, herbicides, and others chemical. This

145 has affected aquatic communities and curtailed water consumption (Poquet M. E. 2007).

146 Rainfall is around $744 \mathrm{~mm} /$ year, and the region is composed by two natural zones: in

147 the western part there is a heavily forested limestone plateau with shallow soils having

148 high infiltration potential, and in the eastern part there is a more humid clayey plain,

149 with deeper soils on a slight slope. In the entire region, tillage is limited by shallow

150 soils, with depth rarely exceeding $30 \mathrm{~cm}$. Those farmers who remain tilling their soils

151 have fields on medium-depth to deep soils, located mainly on the clay plain.

152 In the Ituporanga (SC / Brazil) region, tillage practices are marked by intense 153 plowing and disk harrowing, especially in areas grown with onions, the region's main 154 crop. The intense plowing leads to soil compaction, and intense rainfalls in some 155 periods of the year cause important erosion events. The Itajaí-Açú River crosses the 156 municipality, and the annual average rainfall is around $1400 \mathrm{~mm}$. Soils in that region are 157 predominantly Cambisol and Gleysol (WRB/FAO 2014), distributed in various types of 158 relief, most of them subject to high runoff potential. Table 1 summarizes the most common practices in the three different cropping systems found in both regions.

Table 2: Characteristics of the conventional soil tillage, minimal tillage and notillage systems.

\begin{tabular}{|c|c|c|c|}
\hline \multirow[t]{2}{*}{ Characteristics of crops } & \multicolumn{3}{|c|}{ Farming/cropping System } \\
\hline & Conventional & Minimal tillage & No-tillage \\
\hline Tillage & Deep & Reduced & $\begin{array}{c}\text { Only in the crop row, } 2 \text { to } 10 \\
\text { cm depth }\end{array}$ \\
\hline Plowing & $\begin{array}{c}\text { Twice a year, } 10 \text { to } 20 \mathrm{~cm} \\
\text { depth }\end{array}$ & Absent & Absent \\
\hline Harrowing & $\begin{array}{c}\text { Twice a year, } 5 \text { to } 10 \mathrm{~cm} \\
\text { depth }\end{array}$ & $\begin{array}{l}\text { Once or twice a year, } 5 \text { to } \\
10 \mathrm{~cm} \text { depth }\end{array}$ & Absent \\
\hline Subsoiler & Absent & $\begin{array}{c}\text { Once or twice a year, } 8 \text { to } \\
15 \mathrm{~cm} \text { depth }\end{array}$ & Absent \\
\hline Crop residues & Incorporated into the soil & Incorporated into the soil & Over the soil \\
\hline
\end{tabular}

The study was carried out from April to July 2009 in the French region, and from

164 August to December 2010 in the Brazilian region. Indicator calculations were then performed for each field and each farm. practices, and their effects on treatments and on the environment. 
In Is-sur-Tille $\left(\mathrm{N} 47^{\circ} 31^{\prime} 00^{\prime \prime} \mathrm{E} 05^{\circ} 06^{\prime} 00^{\prime \prime}\right)$ the study was carried out with ten 170 farmers belonging to the Group of Studies and Agricultural Development (GSAD), 171 which comprises 35 farmers totaling 7.000 ha, of which 2.000 ha are under no tillage 172 (NT) since 2009. Three of the ten participants used conventional tillage with plowing, 173 four adopted minimum tillage (MT), two used no tillage (NT) system, and one used MT 174 and NT. The fields studied, ranging from 4,3 to 52,0 hectares, were located on smooth 175 slopes (3 to $20 \%$ ), generally near watercourses. The crops present in this region were 176 winter wheat, winter barley and rapeseed.

177 In Ituporanga (S27 $\left.24^{\prime} 52^{\prime \prime} \mathrm{W} 49^{\circ} 36^{\prime} 9^{\prime \prime}\right), 13$ farmers participated in the study; five 178 of them used conventional tillage with plowing, four used MT, three used NT, and one used MT and NT. The fields, ranging from 2 to 12 ha, in general $1.0 \mathrm{~km}$ far from watercourses, had slopes with medium to high inclination (20 to $45 \%$ ). The crops present in this region were tobacco, onion and corn.

To obtain the data, we studied a field of each crop from the crop-succession adopted in each farm. Each farmer defined the field with the largest representativeness of the respective crop.

\subsection{Active Substances}

The impact of each active substance was evaluated to determine their environmental risk, according to some characteristics of the compound, as example, the risk in assessing the aquatic environment, the leaching potential, the volatilization potential and the persistence.

\section{RESULTS AND DISCUSSION}

I-phyma values were variable in three farming systems (Table 4). Index variability were strongly linked to three factors that affects I-phyma, environment characteristics, as fields near rivers and soil type, active substances (AS) used and their doses, and agricultures techniques used by farmers.

Soils are a key component that rule many processes on Earth and soil texture is an important characteristic to water fluxes. The region of Is-sur-Tille has high pesticide leaching potential, due to clayey texture, low content of organic matter and shallow soils, environment-linked characteristics that reduce RESO indexes. The texture has a 
generally increases water holding capacity and conductivity (Saxton and Rawls, 2006).

201 Moreover, shallow soils are strong influenced by bedrocks and presents high spatial variability of hydraulic conductivity and water infiltration (Pedron et al., 2011). The water flow in these soils is complex and the groundwater module of I-Phy relies on GUS-index, neglecting preferential flow and, consequently, can underestimate pesticide leaching (Lindhal et al., 2012).

The results also varied significantly due to phytosanitary control techniques, as shown by Combret et al. (2007), who observed that sprays carried by airplanes and tractor led to differences in 4.0 points in their final I-Phyma index, due to the impact on AS's drift by technique employed.

Active substances also had an important role in environmental impact, as is the case of isoproturon, 2,4-D - MCPA, trifluralin, metazachlor, quinmerac, chlormequat and alphamethrin (Table 3), even then presents distinct aspects regarding environmental

213 patterns and human health impacts. Isoproturon, as example, shows a dose-dependent 214 increase in its persistence and low affinity for soil adsorption (Papadopoulou et al, 215 2016) leading to high leaching potential. Whilst, the exposure to 2,4-D - MCPA are 216 linked to some cancers and other diseases (Mills, et al., 2005; Hartge et al., 2005), 217 although the studies are not conclusive in some aspects like the effects of association of 218 2,4-D and MCPA (Stackelberg, 2013).

Farmers applied high doses of these substances, which have toxicity to humans and the environment, besides a high risk of volatilization, leaching, and persistence in environment.

Those factors reduce scores when they are present in phytosanitary treatments. Tixier et al. (2007) found significant differences in environmental contamination indicators due to the characteristics of specific AS. However, glyphosate ${ }^{\circledR}$ was applied at high doses in all NT fields. Environmental contamination risks of this molecule are considered low in I-Phy environmental modules (Table 3).

Therefore, it is not possible to infer, per the I- Phy indicator, that high doses of glyphosate ${ }^{\circledR}$ in NT induce strong impacts on the environment. Despite the indicator is sensitive to high doses, glyphosate presents low environmental toxicity because its values of some parameters, e.g., GUS, half-life, aquatox. 
Table 4: The descriptive Statistics of I-phyma results for crops in the three

232 different systems

\begin{tabular}{|c|c|c|c|c|c|c|c|}
\hline System & Crop & Mean of fields & $\begin{array}{l}\text { Std. } \\
\text { Dev. }\end{array}$ & Min & Max & $\begin{array}{c}\text { System } \\
\text { Mean }\end{array}$ & $\begin{array}{c}\text { System } \\
\text { Std.Dev. }\end{array}$ \\
\hline \multirow{5}{*}{ 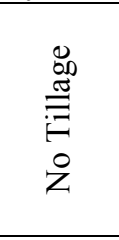 } & Tobacco & 7,40 & 2,26 & 5,8 & 9 & \multirow{5}{*}{7,5} & \multirow{5}{*}{1,49} \\
\hline & Onion & 9,05 & 0,21 & 8,9 & 9,2 & & \\
\hline & Rapeseed & 8,10 & 1,13 & 7,3 & 8,9 & & \\
\hline & Winter wheat & 7,33 & 0,67 & 6,6 & 7,9 & & \\
\hline & Winter barley & 6,30 & 1,91 & 5,2 & 8,5 & & \\
\hline \multirow{5}{*}{ 祃 } & Tobacco & 8,20 & 0,85 & 7,6 & 8,8 & \multirow{5}{*}{6,37} & \multirow{5}{*}{1,88} \\
\hline & Onion & 8,00 & 0,71 & 7,5 & 8,5 & & \\
\hline & Rapeseed & 6,30 & 2,01 & 2,8 & 7,9 & & \\
\hline & Winter wheat & 6,35 & 1,29 & 5 & 8,1 & & \\
\hline & Winter barley & 4,75 & 1,97 & 2,1 & 6,8 & & \\
\hline \multirow{5}{*}{ 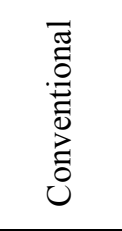 } & Tobacco & 8,20 & 0,14 & 8,1 & 8,3 & \multirow{5}{*}{6,69} & \multirow{5}{*}{1,87} \\
\hline & Onion & 6,60 & 2,13 & 4,3 & 8,5 & & \\
\hline & Rapeseed & 6,60 & 0,79 & 5,7 & 7,2 & & \\
\hline & Winter wheat & 6,47 & 2,10 & 4,4 & 8,6 & & \\
\hline & Winter barley & 6,07 & 3,20 & 2,4 & 8,3 & & \\
\hline
\end{tabular}



necessary or done in inappropriate periods, all contribute to high environment

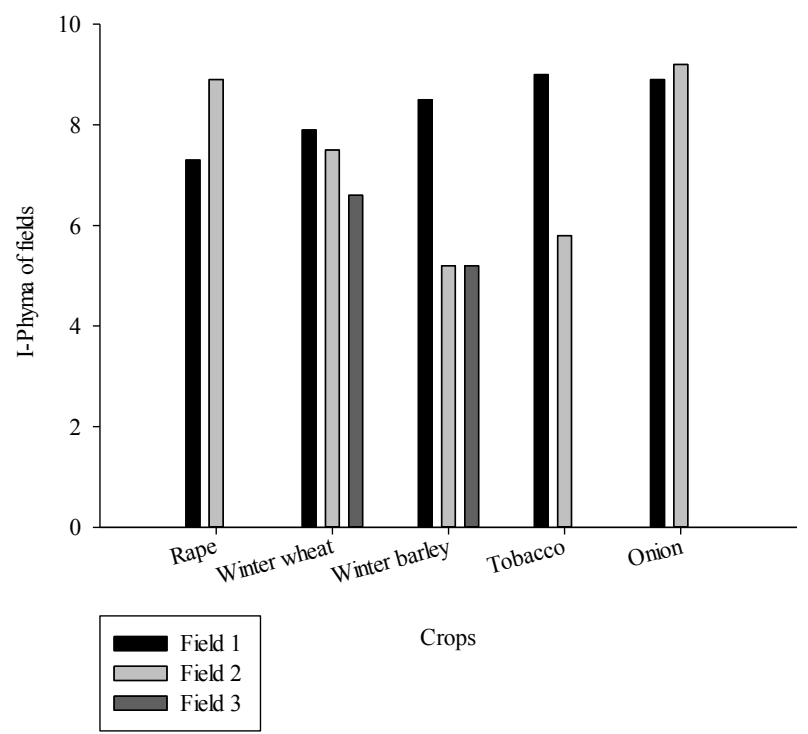

237 systems in Is-sur-Tille, difficulties in phytosanitary control during cultivation of winter 238 barley stands out in all cropping system. Figures 3, 4 and 5 present the I-phyma results 239 of all fields accessed in No Tillage, Minimal Tillage and Conventional system 240 respectively. Winter Wheat and Rapeseed also had problems in the MT system (figure 2414 ), and in CS, only tobacco had good scores (above 7) (Figure 5).

243 Figure 3: I-phyma results for the different fields in No Tillage system

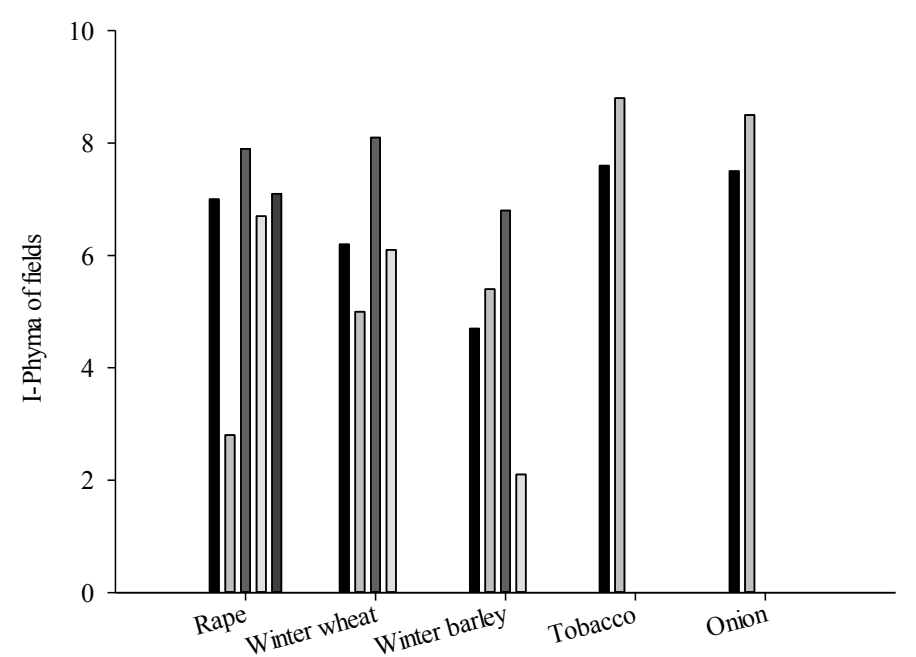


Figure 4: I-phyma results for the different fields in Minimal Tillage system

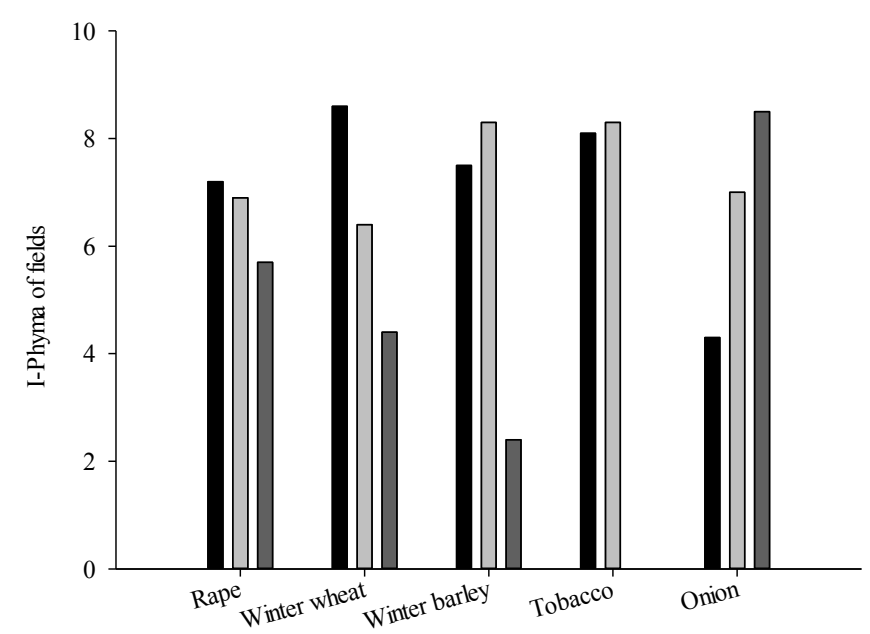
state that plowing induces reduction of certain risks associated with pesticide use. The NT system also showed greater uniformity in results, indicating a standardization of phytosanitary controls and the possibility pesticides uses without an adequate technical support. The perception of farmers the richest and most diverse weed community in NT system could be a factor to increase the use of pesticides, even the tillage system had no effect for cereal production (Mas et al., 2003). In that system, no plot showed extremely high contamination risks (Figure 3), i.e., I-phyma scores under 5.0 points, which indicate high contamination, a condition in which the phytosanitary control program must be reformulated, to reduce contamination levels.

Rapeseed in NT was less pollutant (Figure 3) than in other systems, since it does not receive high pesticide doses, except for glyphosate ${ }^{\circledR}$. In this case, there may be an interaction between crop and cropping system. That is not the case for winter barley in

280 CS, in which scores have high variance (Table 4). This high variance in winter barley is 281 due to treatment management practices, since plot characteristics are similar and did 
282 influence I-phyma variance. High doses and high toxicity risks of substances such as 283 trifluralin, metazachlor, alphamethrin and quinmerac, were responsible for indicator 284 decrease in rapeseed grown in MT and CS systems.

285 Environmental characteristics may either enhance or reduce contamination 286 chances, as observed in the work by Combret et al. (2007), in which environmental 287 factors changed results in up to 2,4 I-phyma points. The interaction of soil 288 characteristics and the landscape are important to determine the behavior of pesticides 289 on the environment, e.g., the transference of chemicals from soil to water is fewer from 290 a deep and clayey profile on a flat relief, under a system which maintain plants on the 291 surface than a sandy soil or even a clayey one located in a steeper region. Rossa et al. 292 (2017), shows that river contamination increases when it drains areas with contaminated 293 plots, highlighting the importance of consider the watershed scale to a more integrative 294 approach management.

295 Winter wheat received high doses of pollutant AS (2,4- MCPA, mécoprop-P, 296 chlortoluron) in CS. However, it showed no noticeable global changes, having a 297 reasonable control in most fields and, at the same time, more uniform environmental 298 impact. This crop demonstrates to perform better in NT where RESO and RESU scores remains at higher levels due to soil cover. Correia et al. (2007) compared atrazine 300 contamination potential in soil under different cropping systems, and found that NT had 301 a greater potential to reduce leaching and groundwater contamination. The role of 302 enhancing the storage of organic matter, especially at the surface layers of long-term 303 areas under NT system must be considered as a factor to improve the biological properties and control the processes of degradation and transference of molecules to the watercourses (Melero et al., 2009).

Spatial isolation (distance from water sources, hedges) of winter wheat fields in

307 CS reduced environmental impact risk. At the same time, there are situations in which 308 environment was unfavorable to the indicators, such as the second plot of winter wheat in MT, which exhibited low I-phyma (Figure 4). In this plot the treatments are 310 considered acceptable, but the plot is vulnerable to environmental contamination, 311 particularly RESO risks. This result corroborates those obtained by Roussel, Cavelier, 312 and van der Werf (2000) in winter wheat fields, where the high risks of runoff and 313 "drift" percentage led to lower scores, indicating higher risk of environmental 314 contamination. 
In the Ituporanga region, indicators of environmental contamination show no strong overall risk. The context must be concerned to this case because in the time data collection took place, corn crop was predominantly from genetically modified (GM) seeds, and, according to the farmers, pesticides were not used due to the absence or low incidence of pests. Therefore, there are no I-Phy indicators of environmental pollution, and it appears that environmental pollution by pesticides in GM corn is void, since farmers grow it in CS, and therefore do not apply any glyphosate ${ }^{\circledR}$ nor any other herbicide. However, according to the farmers, there are already records of progressive incidence of some pests in the crop to which GM corn is supposedly resistant, and pesticides are being reintroduced just can be observed on the fields.

Regarding both places, there were few differences between farming systems, and the results were, in general, satisfactory (Figures 3, 4 and 5), with only a few fields indicating high risks. There are fields in NT system with high performance, and, as noted by Combret et al. (2007), that happens because I-Phy analyses consider soil cover percentage at the time of pesticide application. Due to better soil cover in NT, the direct impact of pesticides on soil are reduced, with higher adsorption rates to crop residues and/or cover crop dry mass, consequently, erosion and runoff will be reduced.

Fields in NT (15 years under NT) have higher contents of organic matter (OM), as compared to systems without crop residues on the soil. RESO risks of NT are also reduced, since I-Phy considers that OM lowers leaching potential. Lower weed incidence, due to the presence of cover crops, also reduces the need for numerous applications of herbicides.

Onion crop yield was generally similar in all three farming systems ( 25 to $35 \mathrm{tha}^{-}$ $\left.{ }^{1}\right)$. There was a reduction in pesticide applications in onion under NT because planting is carried out with seedlings, 70 days after sowing. At that time, seedlings show pseudostem diameter of $0.5 \mathrm{~cm}$ and $15-30 \mathrm{~cm}$ high, unlike other systems, in which sowing is done directly in the field. In some cases, this planting practice (with 70 days) does not require initial pesticide treatments in fields under NT. The plot 1 of onion in

343 CS showed low I-phyma (Figure 5), due to application of pendiméthaline, a very volatile AS, which increases RAIR impacts at high doses.

In CS, the high doses of ioxynyl, and mancozeb also contribute to increased risks on onion crop. Ioxynil has a high risk of human toxicity measured through the ADI, 
347 therefore impacting all three modules RESO, RESU, and AIR (table 2). Mancozeb has a high risk of toxicity for aquatic life, leading to a strong impact on RESU.

MT system did not have any plot with less than 7,0 points I-phyma, and it also showed the lowest variance (table 4). It was the system with greater standardization of controls in both tobacco and onion crops.

In the NT system, only tobacco showed scores under 7,0 on plot 2, due to use of high doses of substances such as chlorpyrifos-ethyl, mancozeb, acephate, iprodione and bifentrine, which may cause greater contamination. Therefore, more effective management of applications, anticipation of treatments, appropriate choice of species for soil cover, and decrease in number of treatments, could reduce contamination risk. Comparing three maize fields under similar environmental conditions and even cropping system, Roussel et al. Roussel, Cavelier, and van der Werf (2000) found different results, which highlights the importance of pest control practice. Farmers can choose doses, number of applications and the AS (more or less toxic), and those choices are determinant of differences in environmental impacts.

362 nevertheless was possible to apply the indicator under subtropical conditions satisfactorily, showing robustness and adaptability. Once the climatic, farm and production characteristics influence on-farm pesticide use (Andert et al., 2015), the demonstration of sensitivity to Brazilian soil and climate open a wide field of possibilities to application to another areas, crops and management conditions.

In Ituporanga, there was not high risk associated with the vulnerability of fields (proximity to rivers or watercourses, shallow soils, surface sealing, etc). For that reason, RESU and RESO scores did not have major reductions, even when doses were high.

373 This fact kept the I-phyma of fields in environmental contamination levels considered tolerable in all systems, with few variations between fields from the same system.

375 However, the indicator does not consider the specific conditions of subtropical climate, 376 where rainfall is higher, with average annual precipitation around 1,400 $\mathrm{mm}$. Therefore, rates of leaching, runoff, and drift are different from those normally included in I-Phy. 
On the other hand, in the French region of Is-sur-Tille, the fields are extremely vulnerable to environmental contamination, since pesticides quickly reach waterways and/or groundwater, which are close to the surface and have little protection to prevent rapid contact with pesticides from fields.

The I-Phy indicator can be useful as a support tool to farmers and research and extension institutions pursuing management practices with lower impact on the environment. However, I-Phy has some limitations that should be reviewed in order to increase the reliability and accuracy of its results. Some proposals are: to include the risks to the operator and to soil macro and microfauna; to have an online platform with constant updating of the database; to include a tropical agriculture platform which considers half-lives of active substances in tropical weather conditions.

\section{CONCLUSIONS}

The I-Phy indicator was able to access the characteristics of systems tested, including under a subtropical condition.

The assessment of environmental impact of pesticide use in conventional tillage system, minimal tillage and no-tillage showed that no-tillage generally presented risks of environmental pollution slightly lower in both regions.

The phytosanitary controls in the region Is-sur-Tille exhibit higher risk of contamination due to high environmental vulnerability of the fields and the numerous applications of active substances with high risks.

The phytosanitary controls in the region Ituporanga exhibit low overall risk of environmental contamination, mainly due to low vulnerability of fields and some good management practices.

\section{REFERENCES}

Andert, S., Bürger, J., Gerowitt, B. On-farm pesticide use in four Northern German regions as influenced by farm and production conditions. Crop Protection. 75: 110. 2015. doi :10.1016/j.cropro.2015.05.002

Bockstaller, C., and Ph Girardin. 2008. "Mode de Calcul Des Indicateurs AgriEnvironnementaux de La Méthode INDIGO." Rapprt Technique, INRA. http://wiki.inra.fr/wiki/deximasc/download/package+MASC/WebHome/Manuel CalculIndicateurINDIGO.pdf. 
Bockstaller, Christian, Laurence Guichard, Olivier Keichinger, Philippe Girardin, Marie-Béatrice Galan, and Gérard Gaillard. 2009. "Comparison of Methods to Assess the Sustainability of Agricultural Systems. A Review." Agronomy for Sustainable Development 29 (1): 223-35. doi:10.1051/agro:2008058.

Bockstaller, Christian, Julie Wohlfahrt, A. Huber, Pierre Hennebert, Frédéric Zahm, Françoise Vernier, O. Keichinger, and P. Girardin. 2008. "Les Indicateurs de Risque de Transfert de Produits Phytosanitaires et Leur Validation: Exemple de L'indicateur I-PHY." Ingénieries Eau Agriculture Territoires, 103-15.

Boyd, Paul M., James L. Baker, Steven K. Mickelson, and Syed I. Ahmed. 2003. "Pesticide Transport with Surface Runoff and Subsurface Drainage through a Vegetative Filter Strip." Transactions of the ASAE 46 (3): 675-84.

Combret, Lucie Polge de, Eliana Freire Gaspar de Carvalho, Pierre Silvie, Eric Scopel, Jean-Louis Bélot, and Alicio Alves Pinto. 2007. "Utilização Do Indicador AgroEcológico I-PHY Para Avaliação Do Potencial de Impacto Ambiental Da Proteção Fitossanitária Do Algodão No Mato Grosso, Brasil.” In . Vol. 6. Uberlândia.

Correia, Fábio Veríssimo, Fábio Martins Mercante, Amoacy Carvalho Fabrício, Tacio Mauro Pereira de Campos, Eurípedes Vargas Jr, and Tomaz Langenbach. 2007. "Adsorção de Atrazina Em Solo Tropical Sob Plantio Direto E Convencional." Pesticidas: Revista de Ecotoxicologia E Meio Ambiente 17. http://ojs.c3sl.ufpr.br/ojs/index.php/pesticidas/article/viewArticle/10663.

Ferreira, D.J., Couto, A.C., Oliveira, M.S., Koifman, S. 2013. "In Utero Pesticide Exposure and Leukemia in Brazilian Children $<2$ Years of Age". Environmental Health Perspectives. 121(2):269-276. doi: 10.1289/ehp.1103942.

Flanagan, D. C., and M. A. Nearing. 2000. "SEDIMENT PARTICLE SORTING ON HILLSLOPE PROFILES IN THE WEPP MODEL." Transactions of the ASAE 43 (3): 573-83. doi:10.13031/2013.2737.

Guimarães, R., Asmus, C., Braga, I., Vianna, A. 2011. "Changes in Immune and Endocrine Effect Markers in Adolescents Exposed to Residues of Organochlorine Pesticides in Brazil". Epidemiology. 22: S245-S245. doi: 0.1097/01.ede.0000392442.80245.d5.

Hartge, P., Colt, J. S., Severson, R. K. "Residential herbicide use and risk of nonHodgkin lymphoma," Cancer Epidemiology Biomarkers and Prevention, vol. 14, no. 4, pp. 934-937, 2005.

Hernández-Hernández, Carlos N.A., Javier Valle-Mora, Antonio SantiestebanHernández, and Ricardo Bello-Mendoza. 2007. "Comparative Ecological Risks of Pesticides Used in Plantation Production of Papaya: Application of the SYNOPS Indicator." Science of The Total Environment 381 (1-3): 112-25. doi:10.1016/j.scitotenv.2007.03.014.

Krawczyk, N., Meyer, A,. Abreu-Villaca, Y,. Filgueiras, C., Fonseca C.. Lima, J. 2014. " Suicide mortality among agricultural workers in a region with intensive tobacco farming and use of pesticides in Brazil". Toxicology Letters. 229:S107. doi: 10.1016/j.toxlet.2014.06.390.

Lindhal, A. M. L., and Bockstaller, C. 2012. "An indicator of pesticide leaching risk to groundwater". Ecological Indicators 23: 95-108. doi:10.1016/j.ecolind.2012.03.014

Mas, M. T., Verdú, A. M. C. 2003. "Tillage system effects on weed communities in a 4year crop rotation under Mediterranean dryland conditions." Soil and Tillage Research 74 (1): 15-24. doi :10.1016/S0167-1987(03)00079-5 
Melero, S., López-Garrido, R., Murillo, J. M., Moreno, F. 2009. "Conservation tillage: Short- and long-term effects on soil carbon fractions and enzymatic activities under Mediterranean conditions." Soil \& Tillage Research 104: 292-298. doi:10.1016/j.still.2009.04.001

Mills, P. K., Yang, R. and D. Riordan, "Lymphohematopoietic cancers in the United Farm Workers of America (UFW), 1988-2001," Cancer Causes and Control, vol. 16, no. 7, pp. 823-830, 2005.

Papadopoulou, E. S., Karas, P. A., Nikolaki, S., Storck, V., Ferrari, F., Trevisan, M., Tsiamis, G., Martin-Laurent, F., Karpouzas, D.G. 2016. "Dissipation and adsorption of isoproturon, tebuconazole, chlorpyrifos and their main transformation products under laboratory and field conditions" Science of the Total Environment 569-570: 86-96. http://dx.doi.org/10.1016/j.scitotenv.2016.06.133

Pedron, F. A., Fink, J. R., Rodrigues, M. F., and Azevedo, A. C. 2011. "Hydraulic Conductivity and Water Retention in Leptosols-Regosols and Saprolite Derived from Sandstone, Brazil." Revista Brasileira de Ciência do Solo (35): 1253-1262. doi: 10.1590/S0100-06832011000400018

Poquet M. E. 2007. "Contrats de Rivières Des Bassins Versants de La Bèze/Albane et de La Tille -Côte d'Or (21)- Elaboration Des Dossiers Sommaires de Candidature." Travail de Fin d'Etude pour l'obtention du diplôme d'Ingénieur de l'ENGEES.

Rossa, P. D., Jannoyer, M., Mottes, C., Plet, J., Bazizi, A., Arnaud, L., Jestin, A., Woignier, T., Gaude, J. M., Cattan, F. 2017. "Linking current river pollution to historical pesticide use: Insights for territorial management?" Science of the Total Environment. doi :10.1016/j.scitotenv.2016.07.065

Roussel, Olivier, Alain Cavelier, and Hayo MG van der Werf. 2000. "Adaptation and Use of a Fuzzy Expert System to Assess the Environmental Effect of Pesticides Applied to Field Crops." Agriculture, Ecosystems \& Environment 80 (1): 14358.

Stackelberg, K. A. 2013. "Systematic Review of Carcinogenic Outcomes and Potential Mechanisms from Exposure to 2,4-D and MCPA in the Environment." Journal of Toxicology doi :10.1155/2013/371610.

Saxton, K. E., and Rawls, W. J. 2006. "Soil Water Characteristic Estimates by Texture and Organic Matter for Hydrologic Solutions." Soil Science Society of America Journal 70: 1569-1578. doi: 10.2136/sssaj2005.0117.

Segatto, M.M., Bonamigo, R.R., Hohmann, C.B., Muller, K.R., Bakos, L., Mastroeni, S., Fortes, C. " Residential and occupational exposure to pesticides may increase risk for cutaneous melanoma: a case-control study conducted in the south of Brazil". 2015. International Journal Of Dermatology. 54(12):e527-538. doi: $10.1111 / \mathrm{ijd} .12826$

Thiollet-Scholtus, Marie, and Christian Bockstaller. 2015. "Using Indicators to Assess the Environmental Impacts of Wine Growing Activity: The INDIGO® Method." European Journal of Agronomy 62 (January): 13-25. doi:10.1016/j.eja.2014.09.001.

Tixier, P., E. Malézieux, M. Dorel, C. Bockstaller, and P. Girardin. 2007. "Rpest-An Indicator Linked to a Crop Model to Assess the Dynamics of the Risk of Pesticide Water Pollution.” European Journal of Agronomy 26 (2): 71-81. doi:10.1016/j.eja.2006.08.006. 
507 Van der Werf, Hayo MG, and Christophe Zimmer. 1998. "Un Indicateur D'impact 508 Environnemental de Pesticides Basé Sur Un Système Expert À Logique Floue.” $509 \quad$ Courrier de L'environnement de l'INRA 34: 47-66.

510 WRB/FAO. 2014. World Reference Base for Soil Resources 2014 International Soil Classification System for Naming Soils and Creating Legends for Soil Maps. Rome: FAO.

Xie, Hui, Lei Chen, and Zhenyao Shen. 2015. "Assessment of Agricultural Best Management Practices Using Models: Current Issues and Future Perspectives." Water 7 (3): 1088-1108. doi:10.3390/w7031088. 